\title{
Radiation induces the generation of cancer stem cells: A novel mechanism for cancer radioresistance (Review)
}

\author{
FENGSHENG LI ${ }^{1 *}$, KUNMING ZHOU $^{1 *}$, LING GAO $^{2}$, BIN ZHANG $^{3}$, WEI LI ${ }^{1}$, \\ WEIJUAN YAN $^{1}$, XIUJUN SONG ${ }^{1}$, HUIJIE YU ${ }^{1}$, SINIAN WANG ${ }^{1}$, NAN YU $^{1}$ and QISHENG JIANG ${ }^{1}$ \\ ${ }^{1}$ Central Laboratories, The Second Artillery General Hospital; ${ }^{2}$ Key Laboratory of Radiological Protection and \\ Nuclear Emergency, National Institute for Radiological Protection, China Center for Disease Control and Prevention; \\ ${ }^{3}$ Department of Colorectal Disease Surgery, The Second Artillery General Hospital, Beijing 100088, P.R. China
}

Received June 10, 2015; Accepted August 19, 2016

DOI: $10.3892 / 01.2016 .5124$

\begin{abstract}
Radioresistance remains a major obstacle for the radiotherapy treatment of cancer. Previous studies have demonstrated that the radioresistance of cancer is due to the existence of intrinsic cancer stem cells (CSCs), which represent a small, but radioresistant cell subpopulation that exist in heterogeneous tumors. By contrast, non-stem cancer cells are considered to be radiosensitive and thus, easy to kill. However, recent studies have revealed that under conditions of radiation-induced stress, theoretically radiosensitive non-stem cancer cells may undergo dedifferentiation subsequently obtaining the phenotypes and functions of CSCs, including high resistance to radiotherapy, which indicates that radiation may directly result in the generation of novel CSCs from non-stem cancer cells. These findings suggest that in addition to intrinsic CSCs, non-stem cancer cells may also contribute to the relapse and metastasis of cancer following transformation into CSCs. This review aims to investigate the radiation-induced generation of CSCs, its association with epithelial-mesenchymal transition and its significance with regard to the radioresistance of cancer.
\end{abstract}

\section{Contents}

1. Introduction

2. CSCs exhibit a critical function in cancer cell radioresistance

Correspondence to: Professor Qisheng Jiang, Central Laboratories, The Second Artillery General Hospital, 16 Xin Jie Kou Wai Street, Beijing 100088, P.R. China

E-mail: jqs598@sina.com

*Contributed equally

Key words: cancer stem cells, radiotherapy, radioresistance, non-stem cancer cells, dedifferentiation, epithelial-mesenchymal transition
3. Origins of CSCs

4. Radiation induces EMT in cancer

5. Radiation induces the generation of CSCs

6. Conclusion

\section{Introduction}

As one of the main treatments for cancer, radiotherapy has been widely used in the clinic for $>100$ years (1). With the development of advanced radiotherapy techniques, radiotherapy has become an extremely efficacious treatment for cancer. However, radioresistance and subsequent relapse and metastasis of cancer occurs in numerous patients that have received advanced radiotherapy (2). Previous studies have reported that intrinsic cancer stem cells (CSCs), which represent a small subpopulation of cancer cells that exist within heterogeneous tumors, are responsible for radioresistance in various types of cancer (3-6). By contrast, non-stem cancer cells, which are the differentiated progeny of CSCs that account for a substantial part of the tumor, are hypothesized to be radiosensitive and thus easy to kill using radiotherapy, resulting in the short-term regression of tumors.

In 1994, Lapidot first reported the existence of a particular subpopulation of cells in leukemia, which were finally termed CSCs or cancer initiating cells $(7,8)$. CSCs are defined as a small cancer cell population within a tumor that has the capacity to self-renew and differentiate into the heterogeneous lineages of cancer cells that comprise the tumor (9). At present, it is postulated that tumor development is driven by the self-renewal and multi-lineage differentiation of CSCs, while their differentiated offspring do not possess the ability to self-renew and extensively proliferate, therefore losing tumorigenic potential (10). Tumors have been demonstrated to be heterogenic with hierarchical organization (11-13) and CSCs are considered to lie at the peak of the tumor hierarchy (8). Despite accounting for only a small proportion of the tumor mass, CSCs have been identified as the main reason for the development of therapeutic resistance, recurrence and metastasis (14-19), which indicates that the elimination of CSCs, rather than non-stem cancer cells, is important for the treatment of cancer. Therefore, recent studies have focused on developing novel treatment strategies that target CSCs (20-23). 
To study these cells, CSCs must be identified and isolated from the tumor bulk or cancer cell lines. The most widely used method for identifying/isolating CSCs is based on the expression of specific cell surface marker or sets of markers (24). A number of specific cell surface markers of CSCs have been identified in a number of diverse human cancers, such as cluster of differentiation (CD) $34^{+} \mathrm{CD} 38^{-}$for CSCs of acute myelomonocytic leukemia (25) and $\mathrm{CD} 133^{+}$for $\mathrm{CSCs}$ of central nervous system tumors (26) and colon cancer (27). Recently, Schatton et al (24) extensively reviewed the specific cell surface markers of CSCs of diverse human cancers. It has been reported that the activity or expression of certain enzymes and membrane transporters in CSCs are different from that in non-stem cancer cells. For example, the activity of aldehyde dehydrogenase 1 (ALDH1) in CSCs is increased in various cancer types, including breast (28), lung (29) and pancreatic cancer (30). Furthermore, the cell membrane adenosine triphosphate-binding cassette $(\mathrm{ABC})$ transporter is overexpressed in the CSCs of ovarian cancer (31), nasopharyngeal carcinoma (32), glioma (33) and lung cancer (34). Notably an isolation method for CSCs, which is based on the enzymatic activity of ALDH1, has been developed and is now widely accepted (28,35-38). Furthermore, side population assays, a well-known and extensively used technique for isolation of CSCs, are based on the fact that the overexpression of $\mathrm{ABC}$ transporter in CSCs effectively effuse the Hoechst dye (39). In addition to surface markers and functional markers, CSCs exhibit unique characteristics, including upregulation of anti-apoptotic proteins, increased efficiency of DNA repair and dormancy/slow cell cycle kinetics (40). These characteristics, together with functional markers, are reported to contribute to the resistance of CSCs to therapy (41-44).

A recent study revealed that like induced stem cells, non-stem cancer cells can dedifferentiate into CSCs via epithelial-mesenchymal transition (EMT) (45). In addition, it has been reported that radiotherapy induces cancer cells to undergo EMT, which results in the development of cancer cell radioresistance (46). Recent studies have confirmed that radiation can induce non-stem cancer cells to obtain the phenotype and functions of CSCs, including high resistance to radiotherapy $(47,48)$. These results indicate that radiation can directly result in the generation of new CSCs from non-stem cancer cells and that these transformed non-stem cancer cells therefore become radioresistant and thus survive radiotherapy treatment $(47,48)$. These findings indicate that non-stem cancer cells, in addition to intrinsic CSCs, contribute to relapse and metastasis of cancer following transformation into CSCs. This review will investigate the radiation-induced generation of CSCs, its association with EMT and its significance in cancer radioresistance.

\section{CSCs exhibit a critical function in cancer cell radiore- sistance}

Radiotherapy is one of the common approaches for cancer therapy. It may be used alone or in combination with chemotherapy and/or surgery. Radiotherapy has demonstrated therapeutic effects for the majority of cancer types and exhibits curative potential in a number of solid human tumors (49), including head and neck carcinoma (50) and non-small cell lung cancer (51). However, despite continuous advances in radiotherapy technology, a high proportion of patients succumb due to tumor recurrence and metastasis as a result of radioresistant cancer cells (2). Increasing evidence has revealed that CSCs are the main contributor to cancer radioresistance in the majority of tumor types, such as glioblastoma (3), head and neck cancer (4), breast cancer (5) and pancreatic cancer (6). Furthermore, Baumann et al (52) reported that the radioresistance of a tumor depends on the number of CSCs present within the tumor itself. Therefore, it was hypothesized that CSCs are responsible for the failure of radiotherapy (53).

Although the mechanism that confers radioresistance to CSCs remains unclear, significant advances in this area of study have been made. A number of potential factors are hypothesized to be involved in the radioresistance of CSCs. Desai et al (54) demonstrated that altered regulation of DNA repair genes, which contributes to enhanced double-strand break resolution, resulted in the radioresistance of human lung CSCs. Furthermore, compared with adherent prostate cancer cells (prostate cancer non-stem cells), cells in prostatospheres (prostate CSCs) exhibited higher expression levels of DNA repair proteins following exposure to ionizing radiation, which efficiently repair radiation-induced DNA injury (55) and therefore confer a survival advantage to CSCs. Bao et al (16) reported that $\mathrm{CD}_{133^{+}}$glioma stem cells conferred glioma radioresistance via preferential activation of the DNA damage checkpoint response, as well as increased DNA repair capacity. Recently, Diehn et al (17) reported that, compared with non-tumorigenic cells, breast CSCs possessed increased free radical-scavenging ability due to the increased expression of free radical scavenging systems, which may reduce reactive oxygen species-mediated DNA damage and cell death after radiation. The Notch (56), c-Jun N-terminal kinase (57) and protein kinase $\mathrm{C} \delta$ signaling (58) pathways are also hypothesized to contribute to CSC radioresistance.

The tumor microenvironment also contributes to the radioresistance of CSCs. Jamal et al (59) reported that $\mathrm{CD}_{133^{+}}$glioblastoma cells grown as intracranial xenografts repaired DNA damage more efficiently than those grown in vitro, as demonstrated by a more rapid decrease in level of radiation-induced $\gamma \mathrm{H} 2 \mathrm{AX}$ and tumor suppressor p53-binding protein 1 foci, the indicators of DNA damage, in the CD133 glioma cells grown in vivo. In a study using explant model and neurospheres culture models derived from surgical glioblastoma multiforme specimens, radiation was found to significantly reduce neurosphere formation in the neurospheres cultures model, but not in the explant model (60), which confirmed the involvement of the tumor microenvironment in CSC radioresistance.

\section{Origins of CSCs}

Although the function of CSCs in therapy resistance of cancer has been confirmed, the origin of CSCs remains controversial. Several hypotheses regarding the origin of CSCs have been suggested to date, including cell fusion between adult stem cells and transformed or normal somatic cells, horizontal gene transfer from apoptotic cells into normal stem/progenitor cells, chromosome derangements and gene mutations in stem/progenitor and differentiated cells and inflammatory 
microenvironment stimulation, all of which have been reviewed by $\mathrm{Bu}$ and $\mathrm{Cao}$ (61). However, the present review focused on EMT as a potential mechanism by which CSCs are generated.

EMT is a unique dedifferentiation process that is involved in embryonic development, whereby cells lose epithelial features and gain mesenchymal properties (62). EMT has also been identified in cancers derived from numerous tissue types, including esophageal (63), breast (64), colon (65), ovarian (66) and thyroid gland tissues (67). The cells undergoing oncogenic EMT observed in cancer exhibit similar characteristics to those undergoing developmental EMT, such as spindleshaped morphology, loss of cellular polarity, disintegration of tight junctions and adherens junctions, downregulation of E-cadherin (epithelial cell marker) and upregulation of $\mathrm{N}$-cadherin and vimentin (mesenchymal markers) and an increase in migratory and invasive ability. The EMT process transforms the epithelial phenotype exhibited by cancer cells into a mesenchymal phenotype, resulting in cells that are more invasive, metastatic and resistant to therapy (68). Therefore, EMT is hypothesized to promote progression and aggressiveness of tumors (62) and notably, increased expression of EMT markers in tumors is associated with distant metastasis and poor prognosis (69). Therefore, these results indicate an association between EMT and CSCs.

It has been reported that EMT-derived cells exhibit potential for multi-lineage differentiation that is similar to mesenchymal stem cells (70). Furthermore, the induction of the EMT process in immortalized human mammary cells results in the expression of stem cell markers and an increased ability to form mammospheres, which are similar to those of stem cell-like cells isolated from cultured human mammary epithelial cells (45). These findings indicate that EMT generates mammary cells with stem cell properties from normal mammary epithelial cells. Notably, the study also indicated that after undergoing EMT, experimentally immortalized human mammary epithelial cells dedifferentiated into CSCs, as demonstrated by the increased formation of colonies in soft agar suspension culture and tumor spheres, which indicate the in vitro tumorigenicity and stemness of cells, respectively (45). In addition, the in vivo tumorigenic capacity assay also demonstrated that the immortalized human mammary epithelial cells that had undergone EMT formed tumors more efficiently than those that were undergoing the EMT process upon subcutaneously injecting them into athymic nude mice (45). These findings indicate that EMT promotes the generation of CSCs from more differentiated neoplastic cells. Similarly, Morel et al (71) confirmed that breast CSCs possessing stem and tumorigenic traits may be generated from non-tumorigenic mammary epithelial cells through EMT. Another similar study using a breast cancer model also demonstrated that EMT in vivo generates breast CSCs, even if the process of EMT is incomplete or aberrant (72). Furthermore, a clinical study using thyroidectomy specimens obtained from patients with anaplastic thyroid carcinoma (ATC) and contiguous differentiated thyroid carcinoma (DTC) revealed that nestin, a marker for stem cell phenotype, was overexpressed in ATC, while no expression of E-cadherin was observed in ATC. By contrast, contiguous DTC specimens were negative for nestin and positive for E-cadherin expression (67). This study confirmed that
EMT is associated with the acquisition of a stem cell phenotype in ATC, however, the significance of the study is limited by the small case series: The authors suggested that a further study based on a larger series of cases is required.

\section{Radiation induces EMT in cancer}

The association between radiation and EMT has gained increasing attention recently. A number of studies have confirmed that radiation can induce EMT or phenotypic changes similar to EMT (73-75). For example, in KYSE-150R cells, a radioresistant esophageal cancer cell line, phenotypic changes similar to EMT are induced by radiation, including decreased E-cadherin and increased Snail and Twist expressions (76), which are also observed in nasopharyngeal carcinoma (77) and colorectal cancer (78). Furthermore, a number of pathways have been reported to contribute to radiation-induced EMT of cancer cells. In lung cancer cells, radiation increases EMT by regulating epithelial and mesenchymal cell markers via the Janus kinase 2/ p21-activated kinase 1/Snail signaling pathway (79). Furthermore, Yuan et al (80) reported that B lymphoma Mo-MLV insertion region 1 exhibits a central function in the regulation of radiation-induced EMT via activation of phosphoinositide 3-kinase/protein kinase B signaling in breast cancer cells. In addition, in a study using cervical cancer cells, low-dose radiation was demonstrated to activate the nuclear factor- $\kappa \mathrm{B}(\mathrm{NF}-\kappa \mathrm{B})$ pathway, which subsequently resulted in EMT of cervical cancer cells (81).

In contrast with phenotypic changes, the characteristic changes in the behavior of cancer cells that have undergone EMT post-radiation are more attractive to investigators. The finding that cancer cells that have obtained mesenchymal phenotypes by EMT are more resistant to therapy implies that radiation-induced EMT may have conferred radioresistance to these cancer cells, which contribute to the relapse of cancer following radiotherapy. This hypothesis has been confirmed by numerous studies involving various types of cancer. Chang et al (46) revealed that prostate cancer cells exhibiting EMT after radiation therapy become more resistant to radiation. Similar results have also been reported in other types of cancer, including pancreatic cancer (82), colorectal cancer (83), breast cancer (84), lung cancer (79), nasopharyngeal carcinoma (77), hepatocellular carcinoma cells (85) and gastric cancer (86).

\section{Radiation induces the generation of CSCs}

The observation that radiation induces EMT of cancer cells, which drives the dedifferentiation of adult cancer cells into $\mathrm{CSCs}$, indicates that radiation may result in the generation of CSCs from differentiated cancer cells. It has been demonstrated that CSCs can be enriched both in vitro and in vivo by radiation, which indicates the possibility of radiation-induced generation of CSCs. Wang et al (87) demonstrated that the proportion of prostate cancer stem-like cells in a human prostate cancer cell culture increased significantly following exposure to radiation. The authors postulated that radiation eliminated the radiosensitive adult cancer cells in the culture by inducing apoptosis, which resulted in the enrichment of radioresistant CSCs. Al-Assar et al (88) reported that breast 


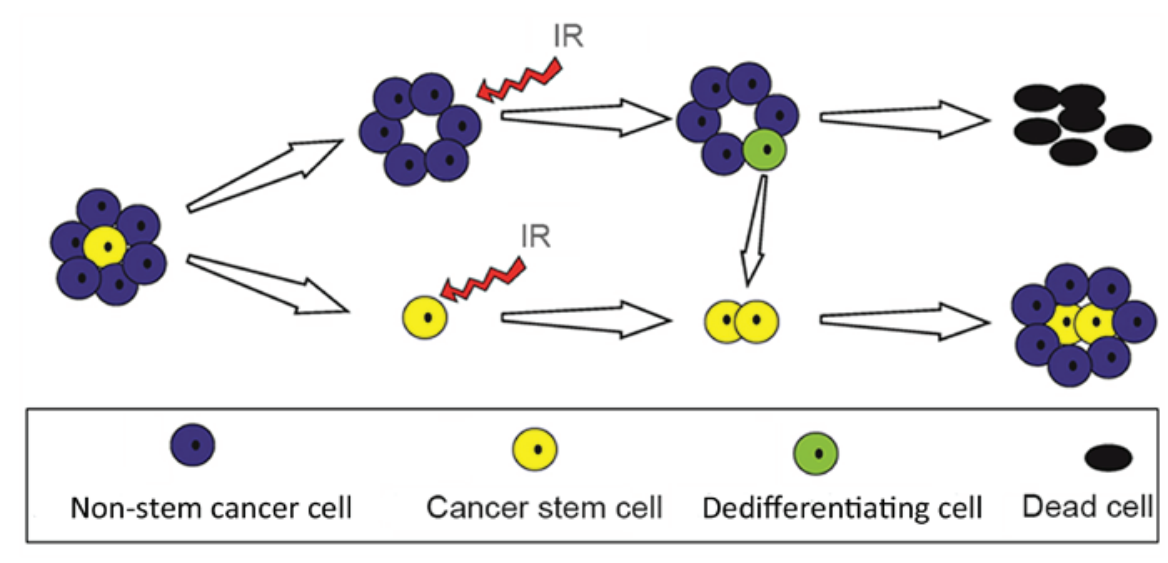

Figure 1. Radiation-induced generation of CSCs contributes to the relapse and metastasis of cancer. CSCs are a small, but radioresistant cell subpopulation that exist within heterogeneous cancer masses. Under conditions of radiation-induced stress, CSCs survive following IR; however, the majority of non-stem cancer cells are killed via various mechanisms such as induction of cell apoptosis or mitotic death. However, a small number of non-stem cancer cells undergo dedifferentiation and transform into CSCs via unknown mechanisms. The newly generated CSCs, together with the intrinsic CSCs, subsequently contribute to relapse and metastasis of cancer. CSCs, cancer stem cells; IR, irradiation.

CSCs in xenografts exposed to radiation were enriched, as demonstrated by an increased number of CD24\%epithelialspecific antigen ${ }^{+}$cancer cells, a marker of breast CSCs, in xenografts. The enrichment of breast CSCs in xenografts exposed to radiation was also considered as the result of different radioresistance between CSCs and adult cancer cells, which was consistent with the aforementioned speculation of Wang et al (87). This explanation was undoubtedly reasonable, but may be not complete. Thus, there may be another reasonable source causing an increase in the absolute number of CSCs and subsequently resulting in CSCs enrichment upon radiation: Radiation-induced generation of CSCs. This source cannot be ignored, since the possibility that cancer cells without stemness markers could obtain stemness markers upon exposure to irradiation was not excluded in the aforementioned studies of Wang et al (87) and Al-Assar et al (88).

In 2012, Lagadec et al (48) revealed for the first time that the enrichment of breast CSCs following radiation was involved in the induction of stem cell-like properties in non-stem cancer cells. In this study, the non-stem breast cancer cells (ALDH1 ${ }^{-}$cells) in single cell suspensions obtained from fresh human breast specimens or established cells lines, were isolated using fluorescence-activated cell sorting after ALDH1 staining (48). These non-stem breast cancer cells were subsequently exposed to various dose of radiation. Following 5 days of irradiation, the number of $\mathrm{ALDH} 1^{+}$cells in the irradiated non-stem breast cancer cell population increased significantly in a dose-dependent manner, which indicated that radiation promoted the non-stem breast cancer cells to exhibit a CSC phenotype. Furthermore, the generated breast CSCs induced by radiation exhibited increased mammosphere formation, increased tumorigenicity and expressed the same stemness-related genes as breast CSCs obtained from non-irradiated samples. Furthermore, these induced breast CSCs exhibited resistance to radiation. This study confirmed that radiation induced the generation of CSCs, which was also reported by Wang et al (89). Additionally, Ghisolfi et al (47) demonstrated that radiation induced stem cell-like properties in non-stem hepatocarcinoma cells, as demonstrated by the findings that non-side population (CSC-depleted population) cells from HepG2 and Huh7 cells exhibited increased sphere formation and stemness gene expression after exposure to radiation.

To date, no studies have investigated the involvement of EMT in the radiation-induced generation of CSCs. However, studies investigating the mechanism underlying radiation-induced generation of CSCs have indicated the potential association between EMT and the generation of radiation-induced CSCs $(90,91)$. Lagadec et al (48) reported that inhibition of Notch receptor expression reduced the ability of the cells to form mammospheres, and therefore concluded that the ionizing radiation-induced translation of non-stem breast cancer cells was Notch-dependent. Previous studies have revealed that Notch signaling mediates EMT via direct or indirect regulation of Snail expression (92-94), a key transcription factor regulating EMT, or via epigenetic mechanisms involving miRNA (95). In another study by Wang et al (89), the expression of NF- $\mathrm{kB}$ in breast cancer cells was elevated after radiation exposure, which contributed to the expression of stemness genes. Inhibition of NF- $\kappa B$ blocked radiation-induced stemness in vitro and in vivo, which indicated that the NF- $\mathrm{KB}$ pathway was involved in the radiation-induced generation of breast CSCs. Similar to the Notch pathway, the NF- $\kappa B$ pathway was also reported to contribute to EMT via transcriptional regulation of genes involved in EMT, including Snail (96), zinc-finger E-box-binding (ZEB)1 and ZEB2 (97) and Twist (98). These findings suggest that EMT is involved in the radiation-induced generation of CSCs.

The observation that radiation induces the generation of CSCs from differentiated cancer cells highlights a novel interaction between radiation and cancer, which may be key to understanding cancer radioresistance. The killing effect of radiation on cancer cells has been well established and is widely used in the clinic as the main approach for cancer therapy. Previous studies have recognized that radiotherapy can effectively kill the majority of differentiated cancer cells in the hierarchical cancer tissue during treatment, however, the intrinsic radioresistant CSCs in the cancer tissue survive 
radiotherapy and therefore this results in the relapse and metastasis of cancer $(2,99)$. The findings that radiation can induce the generation of fresh CSCs from non-stem cancer cells and that the novel CSCs exhibit radioresistant traits similar to the intrinsic CSCs indicates that the newly generated CSCs induced by radiation may be partly responsible for the radioresistance of cancer (Fig. 1).

\section{Conclusion}

Previous studies have established that the relapse and metastasis of cancer is due to the existence of intrinsic, radioresistant CSCs in hierarchical cancer tissue (100-104). Recent evidence indicates that radiation converts non-stem cancer cells into CSCs, which exhibit similar radioresistance to intrinsic CSCs (90). These results provide novel insights with regard to the mechanism of cancer radioresistance, through which the differentiated and radiosensitive non-stem cancer cells that should be killed by radiotherapy are able to survive radiotherapy. After radiotherapy-induced stresses disappear, these newly generated CSCs, together with the intrinsic CSCs, contribute to the relapse and metastasis of cancer. Future studies investigating the underlying pathways driving this transformation may lead to the development of treatment approaches that block the generation of induced CSCs and subsequently enhance the efficacy of radiation treatment.

\section{Acknowledgements}

This study was supported in by The National Science Foundation of China (grant no's. 81202151, 3144039, 81172130 and 31340051) and The Young Scholar Scientific Foundation of China CDC (grant no. 2015A201).

\section{References}

1. Foray N: Claudius Regaud (1870-1940): A pioneer of radiobiology and radiotherapy. Cancer/Radiothérapie 16: 315-321, 2012 (In French).

2. Rycaj K and Tang DG: Cancer stem cells and radioresistance. Int J Radiat Biol 90: 615-621, 2014.

3. Blazek ER, Foutch JL and Maki G: Daoy medulloblastoma cells that express CD133 are radioresistant relative to CD133-cells and the CD133+ sector is enlarged by hypoxia. Int J Radiat Oncol Biol Phys 67: 1-5, 2007.

4. de Jong MC, Pramana J, van der Wal JE, Lacko M, Peutz-Kootstra CJ, de Jong JM, Takes RP, Kaanders JH, van der Laan BF, Wachters J, et al: CD44 expression predicts local recurrence after radiotherapy in larynx cancer. Clin Cancer Res 16: 5329-5338, 2010.

5. Phillips TM, McBride WH and Pajonk F: The response of CD24 (-/low)/CD44+ breast cancer-initiating cells to radiation. J Natl Cancer Inst 98: 1777-1785, 2006.

6. Du Z, Qin R, Wei C, Wang M, Shi C, Tian R and Peng C: Pancreatic cancer cells resistant to chemoradiotherapy rich in 'stem-cell-like' tumor cells. Dig Dis Sci 56: 741-750, 2011.

7. Lapidot T, Sirard C, Vormoor J, Murdoch B, Hoang T, Caceres-Cortes J, Minden M, Paterson B, Caligiuri MA and Dick JE: A cell initiating human acute myeloid leukaemia after transplantation into SCID mice. Nature 367: 645-648, 1994.

8. Zhou BB, Zhang H, Damelin M, Geles KG, Grindley JC and Dirks PB: Tumour-initiating cells: Challenges and opportunities for anticancer drug discovery. Nat Rev Drug Discov 8: 806-823, 2009.

9. Clarke MF, Dick JE, Dirks PB, Eaves CJ, Jamieson CH, Jones DL, Visvader J, Weissman IL and Wahl GM: Cancer stem cells - perspectives on current status and future directions: AACR Workshop on cancer stem cells. Cancer Res 66: 9339-9344, 2006.
10. Lee HE, Kim JH, Kim YJ, Choi SY, Kim SW, Kang E, Chung IY, Kim IA, Kim EJ, Choi Y, et al: An increase in cancer stem cell population after primary systemic therapy is a poor prognostic factor in breast cancer. Br J Cancer 104: 1730-1738, 2011.

11. Anderson K, Lutz C, van Delft FW, Bateman CM, Guo Y, Colman SM, Kempski H, Moorman AV, Titley I, Swansbury J, et al: Genetic variegation of clonal architecture and propagating cells in leukaemia. Nature 469: 356-361, 2011.

12. Mullighan CG, Phillips LA, Su X, Ma J, Miller CB, Shurtleff SA and Downing JR: Genomic analysis of the clonal origins of relapsed acute lymphoblastic leukemia. Science 322: 1377-1380, 2008.

13. Meacham CE and Morrison SJ: Tumour heterogeneity and cancer cell plasticity. Nature 501: 328-337, 2013.

14. Reya T, Morrison SJ, Clarke MF and Weissman IL: Stem cells, cancer, and cancer stem cells. Nature 414: 105-111, 2001.

15. Civenni G, Walter A, Kobert N, Mihic-Probst D, Zipser M, Belloni B, Seifert B, Moch H, Dummer R, van den Broek M and Sommer L: Human CD271-positive melanoma stem cells associated with metastasis establish tumor heterogeneity and long-term growth. Cancer Res 71: 3098-3109, 2011.

16. Bao S, Wu Q, McLendon RE, Hao Y, Shi Q, Hjelmeland AB, Dewhirst MW, Bigner DD and Rich JN: Glioma stem cells promote radioresistance by preferential activation of the DNA damage response. Nature 444: 756-760, 2006.

17. Diehn M, Cho RW, Lobo NA, Kalisky T, Dorie MJ, Kulp AN, Qian D, Lam JS, Ailles LE, Wong M, et al: Association of reactive oxygen species levels and radioresistance in cancer stem cells. Nature 458: 780-783, 2009.

18. Oravecz-Wilson KI, Philips ST, Yilmaz OH, Ames HM, Li L, Crawford BD, Gauvin AM, Lucas PC, Sitwala K, Downing JR, et al: Persistence of leukemia-initiating cells in a conditional knockin model of an imatinib-responsive myeloproliferative disorder. Cancer Cell 16: 137-148, 2009.

19. Zhao C, Chen A, Jamieson CH, Fereshteh M, Abrahamsson A, Blum J, Kwon HY, Kim J, Chute JP, Rizzieri D, et al: Hedgehog signalling is essential for maintenance of cancer stem cells in myeloid leukaemia. Nature 458: 776-779, 2009.

20. Schatton T, Murphy GF, Frank NY, Yamaura K, Waaga-Gasser AM, Gasser M, Zhan Q, Jordan S, Duncan LM, Weishaupt $\mathrm{C}$, et al: Identification of cells initiating human melanomas. Nature 451: 345-349, 2008

21. Yang ZF, Ho DW, Ng MN, Lau CK, Yu WC, Ngai P, Chu PW, Lam CT, Poon RT and Fan ST: Significance of CD90+ cancer stem cells in human liver cancer. Cancer Cell 13: 153-166, 2008.

22. Eriksson M, Guse K, Bauerschmitz G, Virkkunen P, Tarkkanen M, Tanner M, Hakkarainen T, Kanerva A, Desmond RA, Pesonen S and Hemminki A: Oncolytic adenoviruses kill breast cancer initiating CD44+CD24-/low cells. Mol Ther 15: 2088-2093, 2007.

23. Jiang H, Gomez-Manzano C, Aoki H, Alonso MM, Kondo S, McCormick F, Xu J, Kondo Y, Bekele BN, Colman H, et al: Examination of the therapeutic potential of Delta-24-RGD in brain tumor stem cells: Role of autophagic cell death. J Natl Cancer Inst 99: 1410-1414, 2007.

24. Schatton T, Frank NY and Frank MH: Identification and targeting of cancer stem cells. Bioessays 31: 1038-1049, 2009.

25. Ishikawa F, Yoshida S, Saito Y, Hijikata A, Kitamura H, Tanaka S, Nakamura R, Tanaka T, Tomiyama H, Saito N, et al: Chemotherapy-resistant human AML stem cells home to and engraft within the bone-marrow endosteal region. Nat Biotechnol 25: 1315-1321, 2007.

26. Singh SK, Hawkins C, Clarke ID, Squire JA, Bayani J, Hide T, Henkelman RM, Cusimano MD and Dirks PB: Identification of human brain tumour initiating cells. Nature 432: 396-401, 2004.

27. O'Brien CA, Pollett A, Gallinger S and Dick JE: A human colon cancer cell capable of initiating tumour growth in immunodeficient mice. Nature 445: 106-110, 2007.

28. Ginestier C, Hur MH, Charafe-Jauffret E, Monville F, Dutcher J, Brown M, Jacquemier J, Viens P, Kleer CG, Liu S, et al: ALDH1 is a marker of normal and malignant human mammary stem cells and a predictor of poor clinical outcome. Cell Stem Cell 1: 555-567, 2007.

29. Sullivan JP, Spinola M, Dodge M, Raso MG, Behrens C, Gao B, Schuster K, Shao C, Larsen JE, Sullivan LA, et al: Aldehyde dehydrogenase activity selects for lung adenocarcinoma stem cells dependent on notch signaling. Cancer Res 70: 9937-9948, 2010.

30. Kim MP, Fleming JB, Wang H, Abbruzzese JL, Choi W, Kopetz S, McConkey DJ, Evans DB and Gallick GE: ALDH activity selectively defines an enhanced tumor-initiating cell population relative to $\mathrm{CD} 133$ expression in human pancreatic adenocarcinoma. PLoS One 6: e20636, 2011. 
31. Hu L, McArthur C and Jaffe RB: Ovarian cancer stem-like side-population cells are tumourigenic and chemoresistant. Br J Cancer 102: 1276-1283, 2010.

32. Wang J, Guo LP, Chen LZ, Zeng YX and Lu SH: Identification of cancer stem cell-like side population cells in human nasopharyngeal carcinoma cell line. Cancer Res 67: 3716-3724, 2007.

33. Kondo T, Setoguchi T and Taga T: Persistence of a small subpopulation of cancer stem-like cells in the C6 glioma cell line. Proc Natl Acad Sci USA 101: 781-786, 2004.

34. Ho MM, Ng AV, Lam S and Hung JY: Side population in human lung cancer cell lines and tumors is enriched with stem-like cancer cells. Cancer Res 67: 4827-4833, 2007.

35. Huang EH, Hynes MJ, Zhang T, Ginestier C, Dontu G, Appelman H, Fields JZ, Wicha MS and Boman BM: Aldehyde dehydrogenase 1 is a marker for normal and malignant human colonic stem cells (SC) and tracks SC overpopulation during colon tumorigenesis. Cancer Res 69: 3382-3389, 2009.

36. Dalerba P, Dylla SJ, Park IK, Liu R, Wang X, Cho RW, Hoey T, Gurney A, Huang EH, Simeone DM, et al: Phenotypic characterization of human colorectal cancer stem cells. Proc Natl Acad Sci USA 104: 10158-10163, 2007.

37. Ma S, Chan KW, Lee TK, Tang KH, Wo JY, Zheng BJ and Guan XY: Aldehyde dehydrogenase discriminates the CD133 liver cancer stem cell populations. Mol Cancer Res 6: 1146-1153, 2008.

38. Jiang F, Qiu Q, Khanna A, Todd NW, Deepak J, Xing L, Wang H, Liu Z, Su Y, Stass SA and Katz RL: Aldehyde dehydrogenase 1 is a tumor stem cell-associated marker in lung cancer. Mol Cancer Res 7: 330-338, 2009

39. Broadley KW, Hunn MK, Farrand KJ, Price KM, Grasso C, Miller RJ, Hermans IF and McConnell MJ: Side population is not necessary or sufficient for a cancer stem cell phenotype in glioblastoma multiforme. Stem Cells 29: 452-461, 2011.

40. Alison MR, Lin WR, Lim SM and Nicholson LJ: Cancer stem cells: In the line of fire. Cancer Treat Rev 38: 589-598, 2012.

41. Rich JN and Bao S: Chemotherapy and cancer stem cells. Cell Stem Cell 1: 353-355, 2007 .

42. Morrison R, Schleicher SM, Sun Y, Niermann KJ, Kim S, Spratt DE, Chung CH and Lu B: Targeting the mechanisms of resistance to chemotherapy and radiotherapy with the cancer stem cell hypothesis. J Oncol 2011: 941876, 2011.

43. Hill RP, Marie-Egyptienne DT and Hedley DW: Cancer stem cells, hypoxia and metastasis. Semin Radiat Oncol 19: 106-111, 2009.

44. Signore M, Ricci-Vitiani L and De Maria R: Targeting apoptosis pathways in cancer stem cells. Cancer Lett 332: 374-382, 2013.

45. Mani SA, Guo W, Liao MJ, Eaton EN, Ayyanan A, Zhou AY, Brooks M, Reinhard F, Zhang CC, Shipitsin M, et al: The epithelial-mesenchymal transition generates cells with properties of stem cells. Cell 133: 704-715, 2008

46. Chang L, Graham PH, Hao J, Bucci J, Cozzi PJ, Kearsley JH and $\mathrm{Li} \mathrm{Y}$ : Emerging roles of radioresistance in prostate cancer metastasis and radiation therapy. Cancer Metastasis Rev 33 469-496, 2014

47. Ghisolfi L, Keates AC, Hu X, Lee DK and Li CJ: Ionizing radiation induces stemness in cancer cells. PLoS One 7: e43628, 2012.

48. Lagadec C, Vlashi E, Della Donna L, Dekmezian C and Pajonk F: Radiation-induced reprogramming of breast cancer cells. Stem Cells 30: 833-844, 2012.

49. Krause M, Yaromina A, Eicheler W, Koch U and Baumann M: Cancer stem cells: Targets and potential biomarkers for radiotherapy. Clin Cancer Res 17: 7224-7229, 2011.

50. Budach V, Stuschke M, Budach W, Baumann M, Geismar D, Grabenbauer G, Lammert I, Jahnke K, Stueben G, Herrmann T, et al: Hyperfractionated accelerated chemoradiation with concurrent fluorouracil-mitomycin is more effective than dose-escalated hyperfractionated accelerated radiation therapy alone in locally advanced head and neck cancer: Final results of the radiotherapy cooperative clinical trials group of the German Cancer Society 95-06 Prospective Randomized Trial. J Clin Oncol 23: 1125-1135, 2005.

51. Baumann M, Herrmann T, Koch R, Matthiessen W, Appold S, Wahlers B, Kepka L, Marschke G, Feltl D, Fietkau R, et al; CHARTWEL-Bronchus studygroup: Final results of the randomized phase III CHARTWEL-trial (ARO 97-1) comparing hyperfractionated-accelerated versus conventionally fractionated radiotherapy in non-small cell lung cancer (NSCLC). Radiother Oncol 100: 76-85, 2011.

52. Baumann M, Krause M, Thames H, Trott K and Zips D: Cancer stem cells and radiotherapy. Int J Radiat Biol 85: 391-402, 2009.
53. Baumann M, Krause M and Hill R: Exploring the role of cancer stem cells in radioresistance. Nat Rev Cancer 8: 545-554, 2008.

54. Desai A, Webb B and Gerson SL: CD133+ cells contribute to radioresistance via altered regulation of DNA repair genes in human lung cancer cells. Radiother Oncol 110: 538-545, 2014.

55. Kim YS, Kang MJ and Cho YM: Low production of reactive oxygen species and high DNA repair: Mechanism of radioresistance of prostate cancer stem cells. Anticancer Res 33 4469-4474, 2013

56. Lagadec C, Vlashi E, Alhiyari Y, Phillips TM, Bochkur Dratver $\mathrm{M}$ and Pajonk F: Radiation-induced Notch signaling in breast cancer stem cells. Int J Radiat Oncol Biol Phys 87: 609-618, 2013.

57. Yoon CH, Kim MJ, Kim RK, Lim EJ, Choi KS, An S, Hwang SG, Kang SG, Suh Y, Park MJ and Lee SJ: c-Jun N-terminal kinase has a pivotal role in the maintenance of self-renewal and tumorigenicity in glioma stem-like cells. Oncogene 31: 4655-4666, 2012

58. Kim MJ, Kim RK, Yoon CH, An S, Hwang SG, Suh Y, Park MJ, Chung HY, Kim IG and Lee SJ: Importance of PKC $\delta$ signaling in fractionated-radiation-induced expansion of glioma-initiating cells and resistance to cancer treatment. J Cell Sci 124: 3084-3094, 2011.

59. Jamal M, Rath BH, Williams ES, Camphausen K and Tofilon PJ: Microenvironmental regulation of glioblastoma radioresponse. Clin Cancer Res 16: 6049-6059, 2010.

60. Hovinga KE, Shimizu F, Wang R, Panagiotakos G, Van Der Heijden M, Moayedpardazi H, Correia AS, Soulet D, Major T, Menon J and Tabar V: Inhibition of notch signaling in glioblastoma targets cancer stem cells via an endothelial cell intermediate. Stem Cells 28: 1019-1029, 2010.

61. $\mathrm{Bu} \mathrm{Y}$ and Cao D: The origin of cancer stem cells. Front Biosci (Schol Ed) 4: 819-830, 2012.

62. Thiery JP, Acloque H, Huang RY and Nieto MA: Epithelial-mesenchymal transitions in development and disease. Cell 139: 871-890, 2009.

63. Usami Y, Satake S, Nakayama F, Matsumoto M, Ohnuma K, Komori T, Semba S, Ito A and Yokozaki H: Snail-associated epithelial-mesenchymal transition promotes oesophageal squamous cell carcinoma motility and progression. J Pathol 215: 330-339, 2008

64. Trimboli AJ, Fukino K, de Bruin A, Wei G, Shen L, Tanner SM, Creasap N, Rosol TJ, Robinson ML, Eng C, et al: Direct evidence for epithelial-mesenchymal transitions in breast cancer. Cancer Res 68: 937-945, 2008.

65. Brabletz T, Hlubek F, Spaderna S, Schmalhofer O Hiendlmeyer E, Jung A and Kirchner T: Invasion and metastasis in colorectal cancer: Epithelial-mesenchymal transition, mesenchymal-epithelial transition, stem cells and beta-catenin. Cells Tissues Organs 179: 56-65, 2005

66. Vergara D, Merlot B, Lucot JP, Collinet P, Vinatier D, Fournier I and Salzet M: Epithelial-mesenchymal transition in ovarian cancer. Cancer Lett 291: 59-66, 2010.

67. Liu J and Brown RE: Immunohistochemical detection of epithelialmesenchymal transition associated with stemness phenotype in anaplastic thyroid carcinoma. Int J Clin Exp Pathol 3: 755-762, 2010.

68. Shang Y, Cai X and Fan D: Roles of epithelial-mesenchymal transition in cancer drug resistance. Curr Cancer Drug Targets 13: 915-929, 2013

69. Jie D, Zhongmin Z, Guoqing L, Sheng L, Yi Z, Jing W and Liang Z: Positive expression of LSD1 and negative expression of E-cadherin correlate with metastasis and poor prognosis of colon cancer. Dig Dis Sci 58: 1581-1589, 2013.

70. Battula VL, Evans KW, Hollier BG, Shi Y, Marini FC, Ayyanan A, Wang RY, Brisken C, Guerra R, Andreeff M and Mani SA: Epithelial-mesenchymal transition-derived cells exhibit multilineage differentiation potential similar to mesenchymal stem cells. Stem Cells 28: 1435-1445, 2010.

71. Morel AP, Lièvre M, Thomas C, Hinkal G, Ansieau S and Puisieux A: Generation of breast cancer stem cells through epithelial-mesenchymal transition. PLoS One 3: e2888, 2008.

72. Santisteban M, Reiman JM, Asiedu MK, Behrens MD, Nassar A, Kalli KR, Haluska P, Ingle JN, Hartmann LC, Manjili MH, et al: Immune-induced epithelial to mesenchymal transition in vivo generates breast cancer stem cells. Cancer Res 69: 2887-2895, 2009.

73. He E, Pan F, Li G and Li J: Fractionated ionizing radiation promotes epithelial-mesenchymal transition in human esophageal cancer cells through PTEN deficiency-mediated Akt activation. PLoS One 10: e0126149, 2015. 
74. Marie-Egyptienne DT, Lohse I and Hill RP: Cancer stem cells, the epithelial to mesenchymal transition (EMT) and radioresistance: Potential role of hypoxia. Cancer Lett 341: 63-72, 2013.

75. Nagarajan D, Melo T, Deng Z, Almeida C and Zhao W: ERK/ GSK3 $\beta /$ Snail signaling mediates radiation-induced alveolar epithelial-to-mesenchymal transition. Free Radic Biol Med 52: 983-992, 2012.

76. Su H, Jin X, Zhang X, Zhao L, Lin B, Li L, Fei Z, Shen L, Fang Y, $\mathrm{Pan} \mathrm{H}$ and Xie C: FH535 increases the radiosensitivity and reverses epithelial-to-mesenchymal transition of radioresistant esophageal cancer cell line KYSE-150R. J Transl Med 13: 104, 2015.

77.Li G, Liu Y, Su ZW, Ren SL, Liu C, Tian YQ and Qiu YZ: Irradiation induced epithelial-mesenchymal transition in nasopharyngeal carcinoma in vitro. Zhonghua Er Bi Yan Hou Tou Jing Wai Ke Za Zhi 48: 662-667, 2013 (In Chinese).

78. Kawamoto A, Yokoe T, Tanaka K, Saigusa S, Toiyama Y, Yasuda $\mathrm{H}$, Inoue Y, Miki C and Kusunoki M: Radiation induces epithelial-mesenchymal transition in colorectal cancer cells. Oncol Rep 27: 51-57, 2012.

79. Kim E, Youn H, Kwon T, Son B, Kang J, Yang HJ, Seong KM, Kim W and Youn B: PAK1 tyrosine phosphorylation is required to induce epithelial-mesenchymal transition and radioresistance in lung cancer cells. Cancer Res 74: 5520-5531, 2014

80. Yuan W, Yuan Y, Zhang T and Wu S: Role of Bmi-1 in regulation of ionizing irradiation-induced epithelial-mesenchymal transition and migration of breast cancer cells. PLoS One 10: e0118799, 2015.

81. Yan S, Wang Y, Yang Q, Li X, Kong X, Zhang N, Yuan C, Yang N and Kong B: Low-dose radiation-induced epithelial-mesenchymal transition through NF- $\mathrm{KB}$ in cervical cancer cells. Int J Oncol 42: 1801-1806, 2013.

82. Al-Assar O, Demiciorglu F, Lunardi S, Gaspar-Carvalho MM, McKenna WG, Muschel RM and Brunner TB: Contextual regulation of pancreatic cancer stem cell phenotype and radioresistance by pancreatic stellate cells. Radiother Oncol 111: 243-251, 2014

83. Bastos LG, de Marcondes PG, de-Freitas-Junior JC, Leve F, Mencalha AL, de Souza WF, de Araujo WM, Tanaka MN Abdelhay ES and Morgado-Díaz JA: Progeny from irradiated colorectal cancer cells acquire an EMT-like phenotype and activate Wnt/ $\beta$-catenin pathway. J Cell Biochem 115: 2175-2187, 2014.

84.Zhang P, Wei Y, Wang L, Debeb BG, Yuan Y, Zhang J, Yuan J, Wang M, Chen D, Sun Y, et al: ATM-mediated stabilization of ZEB1 promotes DNA damage response and radioresistance through CHK1. Nat Cell Biol 16: 864-875, 2014.

85. Jiang X, Wang J, Zhang K, Tang S, Ren C and Chen Y: The role of CD29-ILK-Akt signaling-mediated epithelial-mesenchymal transition of liver epithelial cells and chemoresistance and radioresistance in hepatocellular carcinoma cells. Med Oncol 32: 141, 2015.

86.Zhang X, Zheng L, Sun Y, Wang T and Wang B: Tangeretin enhances radiosensitivity and inhibits the radiation-induced epithelial-mesenchymal transition of gastric cancer cells. Oncol Rep 34: 302-310, 2015.

87. Wang L, Huang X, Zheng X, Wang X, Li S, Zhang L, Yang Z and Xia Z: Enrichment of prostate cancer stem-like cells from human prostate cancer cell lines by culture in serum-free medium and chemoradiotherapy. Int J Biol Sci 9: 472-479, 2013

88. Al-Assar O, Muschel RJ, Mantoni TS, McKenna WG and Brunner TB: Radiation response of cancer stem-like cells from established human cell lines after sorting for surface markers. Int J Radiat Oncol Biol Phys 75: 1216-1225, 2009.
89. Wang Y, Li W, Patel SS, Cong J, Zhang N, Sabbatino F, Liu X, Qi Y, Huang P, Lee H, et al: Blocking the formation of radiation-induced breast cancer stem cells. Oncotarget 5: 3743-3755, 2014

90. Vares G, Cui X, Wang B, Nakajima T and Nenoi M: Generation of breast cancer stem cells by steroid hormones in irradiated human mammary cell lines. PLoS One 8: e77124, 2013.

91. Aravindan S, Ramraj SK, Somasundaram ST, Herman TS and Aravindan N: Polyphenols from marine brown algae target radiotherapy-coordinated EMT and stemness-maintenance in residual pancreatic cancer. Stem Cell Res Ther 6: 182, 2015.

92. Timmerman LA, Grego-Bessa J, Raya A, Bertrán E, Pérez-Pomares JM, Díez J, Aranda S, Palomo S, McCormick F, Izpisúa-Belmonte JC and de la Pompa JL: Notch promotes epithelial-mesenchymal transition during cardiac development and oncogenic transformation. Genes Dev 18: 99-115, 2004

93. Leong KG, Niessen K, Kulic I, Raouf A, Eaves C, Pollet I and Karsan A: Jagged1-mediated Notch activation induces epithelial-to-mesenchymal transition through Slug-induced repression of E-cadherin. J Exp Med 204: 2935-2948, 2007.

94. Sahlgren C, Gustafsson MV, Jin S, Poellinger L and Lendahl U: Notch signaling mediates hypoxia-induced tumor cell migration and invasion. Proc Natl Acad Sci USA 105: 6392-6397, 2008.

95. Yang Y, Ahn YH, Gibbons DL, Zang Y, Lin W, Thilaganathan N, Alvarez CA, Moreira DC, Creighton CJ, Gregory PA, et al: The Notch ligand Jagged 2 promotes lung adenocarcinoma metastasis through a miR-200-dependent pathway in mice. J Clin Invest 121: 1373-1385, 2011.

96. Kim HJ, Litzenburger BC, Cui X, Delgado DA, Grabiner BC, Lin X, Lewis MT, Gottardis MM, Wong TW, Attar RM, et al: Constitutively active type I insulin-like growth factor receptor causes transformation and xenograft growth of immortalized mammary epithelial cells and is accompanied by an epithelial-to-mesenchymal transition mediated by NF-kappaB and snail. Mol Cell Biol 27: 3165-3175, 2007.

97. Chua HL, Bhat-Nakshatri P, Clare SE, Morimiya A, Badve S and Nakshatri H: NF-kappaB represses E-cadherin expression and enhances epithelial to mesenchymal transition of mammary epithelial cells: Potential involvement of ZEB-1 and ZEB-2. Oncogene 26: 711-724, 2007.

98. Sosic D and Olson EN: A new twist on twist - modulation of the NF-kappaB pathway. Cell Cycle 2: 76-78, 2003.

99. Rich JN: Cancer stem cells in radiation resistance. Cancer Res 67: 8980-8984, 2007

100. Mitra A, Mishra L and Li S: EMT, CTCs and CSCs in tumor relapse and drug-resistance. Oncotarget 6: 10697-10711, 2015.

101. He YC, Zhou FL, Shen Y, Liao DF and Cao D: Apoptotic death of cancer stem cells for cancer therapy. Int J Mol Sci 15: 8335-8351, 2014.

102. Dawood S, Austin L and Cristofanilli M: Cancer stem cells: Implications for cancer therapy. Oncology (Williston Park) 28: 1101-1107 and 1110, 2014.

103. Makki J, Myint O, Wynn AA, Samsudin AT and John DV: Expression distribution of cancer stem cells, epithelial to mesenchymal transition, and telomerase activity in breast cancer and their association with clinicopathologic characteristics. Clin Med Insights Pathol 8: 1-16, 2015.

104. Ghisolfi L, Keates AC, Hu X, Lee DK and Li CJ: Ionizing radiation induces stemness in cancer cells. PLoS One 7: e43628, 2012. 